\title{
SZTUKA WOJNY SUN TZU JAKO PODSTAWA STRATEGII ROZWOJU PERSONELU
}

\section{Wstęp}

Celem opracowania jest zaprezentowanie możliwości wykorzystania koncepcji myślenia lateralnego w odniesieniu do zarządzania zasobami ludzkimi na przykładzie sztuki prowadzenia wojny zaproponowanej przez Sun Tzu w Sztuce wojny i przeprowadzonego wywiadu z ekspertami.

Sun Tzu (VII-VI w. p.n.e.) był jednym z największych myślicieli, strategów i generałów starożytnego Dalekiego Wschodu i autorem najbardziej znanego, najstarszego podręcznika traktującego o sztuce wojennej. Pomimo wielu zmian, które pojawiły się $\mathrm{w}$ teoriach wojennych, treści przez niego przekazywane zadziwiają swoją ponadczasową aktualnością, a dodatkowo są stosowane $\mathrm{z}$ powodzeniem nie tylko w militarnych sferach aktywności społecznej człowieka. „Sztuka wojenna zajmuje się problemami wielce złożonymi, obejmującymi $\mathrm{w}$ różnym stopniu $\mathrm{w}$ zasadzie wszystkie dziedziny życia społeczeństwa"1, dlatego imponująca jest ilość odwołań do traktatu Sun Tzu, które można spotkać w Internecie, księgarniach czy bibliotekach, m.in.: Sztuka wojny. Sztuka marketingu ${ }^{2}$, Sun Tzu. Sztuka wojny dla graczy giełdowych i inwestorów ${ }^{3}$, Sztuka wojny w biznesie ${ }^{4}$, Sztuka wojny w miłości ${ }^{5}$, Sztuka wojny. Sztuka planowania kariery $^{6}$.

Diagnoza i analiza zasadniczej wiedzy obejmującej strategię personalną oraz sztukę wojenną pozwoliły na zaznaczenie obszarów, które można uważać za wspólne. Dotyczą one przede wszystkim: planowania, kierowania ludźmi, przywództwa oraz rozwoju pracowników.

Można wysnuć wniosek, że pomimo istnienia zasadniczych różnic w terminach strategii personalnej i sztuki wojny, zauważalny jest znaczący zbiór elementów, które występują w obu obszarach: celowość działań, rozciągnięcie $\mathrm{w}$ czasie, przebieg podzielony na etapy, posiadanie przez zainteresowane strony indywidualnych zasobów oraz istotna kwestia przygotowania.

\footnotetext{
* Doktorantka, Katedra Zarządzania, Wydział Zarządzania UŁ.

${ }^{1}$ A. Tomaszewski, Podstawowe kategorie sztuki wojennej, AON, Warszawa 1996, s. 5.

${ }^{2}$ G. Gagliardi, Sun Tzu, Sztuka wojny. Sztuka marketingu, Helion, Gliwice 2005.

${ }^{3}$ L. Dean, Sun Tzu, Sztuka wojny dla graczów giełdowych i inwestorów, IFC PRESS, Kraków 1999.

${ }^{4}$ D. G. Krause, Sztuka wojny w biznesie, Helion, Gliwice 2009.

${ }^{5}$ C. Cowan, G. Parent, Sztuka wojny w miłości, Helion, Gliwice 2009.

${ }^{6}$ G. Gagliardi, Sztuka wojny. Sztuka planowania kariery, Helion, Gliwice 2005.
} 
Zarówno wojnę, jak i strategię personalną można podzielić ze względu na kolejne fazy i etapy, gdzie szczególnym przypadkiem jest gloryfikacja działań podejmowanych $\mathrm{w}$ trakcie przygotowań. Otrzymany w toku studiowania wniosek daje możliwość formułowania przekonania o znacznie szerszym zasięgu tej zależności i który nie ogranicza się tylko do jednego zjawiska, ale odnosi się do obszarów wiedzy z zakresu rozwoju strategii personalnej i sztuki wojennej.

\section{Zasady prowadzenie wojny będące przesłanką dla strategii rozwoju personelu}

Każda organizacja, która decyduje się na rozpoczęcie cyklu szkoleń lub w kształtowaniu karier zawodowych upatruje szansy na rozwój personelu, musi opracować skuteczną strategię, która umożliwi sterowanie nimi, zgodnie z własnymi oczekiwaniami. Najważniejszą rolę w jej formułowaniu odgrywa osoba zajmująca się rozwojem personelu (może to być dyrektor, kierownik bądź też specjalista ds. personalnych), gdyż ,jeśli powołany do służby generał przykłada wagę do swojej strategii, może osiągnąć zwycięstwo"7. Strategia w swoim ogólnym założeniu formułuje cele oraz sposoby ich osiągnięcia. Sun Tzu proponuje, aby we wstępnym etapie określić ogólne założenia, będące podstawą w dalszym planowaniu strategii. Najważniejsze wskazówki dla menedżera można ująć w niżej wymienione kategorie.

Jednym z głównych celów przygotowania do strategii rozwoju personelu jest zbieranie różnorodnych informacji, które dadzą możliwość ocenienia i zdiagnozowania własnej sytuacji oraz perspektyw pracowników. Analiza tych podstawowych danych staje się niezbędna w przypadku opracowania ramowego planu działania oraz wyboru adekwatnej do sytuacji taktyki - „z pewnością ten, kto w ogóle nie robi kalkulacji, zaprzepaszcza szansę zwycięstwa" ${ }^{8}$. Z nauk Sun Tzu można wyciągnąć wniosek, iż osoba odpowiedzialna za proces rozwoju personelu, gdy zaniecha lub zlekceważy te czynności nie osiągnie wyznaczonych celów. Musi on poddać bardzo dokładnej ocenie realne zagrożenia i szanse, które występują w otoczeniu oraz słabe i silne strony swojej organizacji - jest to swoistego rodzaju rozpoznawalna analiza SWOT. W następnej kolejności należy sporządzić różnorodne warianty postępowania i każdy z nich odpowiednio, na gruncie zebranych doświadczeń własnych, przedyskutować z całym zespołem, uwzględniając przy tym ewentualne ryzyko oraz płynące korzyści. Warto mieć przygotowanych kilka koncepcji, gdyż „spośród wielu planów, jeden może się powieść, a pozostałe nie"9 - dlatego zawsze należy drobiazgowo analizować

\footnotetext{
${ }^{7}$ Sun Tzu, Sztuka wojny, Helion, Gliwice 2012, s. 52.

${ }^{8}$ Ibidem, s. 52.

${ }^{9}$ Ibidem, s. 53.
} 
każdą sytuację, aby uwarunkowania, które jej towarzyszą były na wskroś znane $\mathrm{i}$ aby $\mathrm{w}$ nieodpowiednim momencie nie okazały się przeszkodą $\mathrm{w}$ realizacji zamierzonych celów.

Decyzje, które będą podejmowane w trakcie procesu rozwoju personelu, nie powinny być pochopne, jednak nie należy zbyt długo zwlekać z reakcją. Istotną kwestią na etapie przygotowań jest opracowanie listy ewentualnych rozwiązań i zaleceń. Oczywiście, nie da się rozważyć wszystkich wariantów, jednak wcześniejsze przedyskutowanie różnorodnych możliwości zmniejszy szansę na niepowodzenie całego, jakże złożonego przedsięwzięcia - „w czasie wojny najważniejszą rzeczą jest szybkość działania"10. Dostępne dzięki Sun Tzu zalecenia zwracają uwagę również na fakt, iż dobry menedżer powinien charakteryzować się elastycznością oraz dynamizmem w działaniu.

Zgodnie z nauką wielkiego chińskiego generała, największej siły należy upatrywać nie w tym, co ktoś posiada, ale w kreowanym na ten temat wyobraże-

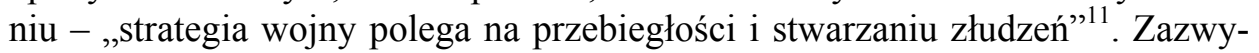
czaj należy manifestować to, co chce się osiągnąć. Należy dążyć do istotnej przewagi konkurencyjnej poprzez naturalne stworzenie wrażenia co do posiadania dużej ilości zasobów, pozycji na rynku i możliwości sprawnego działania.

Syntezując cząstkowe wnioski, można pokusić się o stwierdzenie, że scharakteryzowane zasady stanowią cenne wskazówki dla menedżerów zajmujących się na co dzień rozwojem kadry pracowniczej. Wynika $\mathrm{z}$ nich, iż układając ogólną strategię działania, powinni oni uwzględniać następujące czynniki: głęboką analizę sytuacji, wliczając w to kalkulację skuteczności różnorodnych taktyk oraz opracowanie pomysłów i planów, które wspomogą osiągnięcie zamierzonych celów. Stosując zalecenia Sun Tzu, menedżer mający wsparcie swojego zespołu, może opracować efektywną strategię rozwoju, tak aby z jednej strony dostosować ją do potrzeb pracowników, z drugiej zaś narzucić swój sposób postępowania.

Człowiek podejmujący jakąkolwiek aktywność, za każdym razem jest ukierunkowany na osiągnięcie konkretnego celu. Dzieło Sun Tzu w wielu fragmentach odnosi się do celu prowadzonych działań wojennych - „najważniejszym celem wojny jest zwycięstwo" "12. Należy jednak zaznaczyć, że odczytywanie sentencji w kategorii pokonania przeciwnika, zmierzające do totalnego zaniku jego środków i sił, tak aby nie mógł się już odrodzić, jest błędne. Osoby, które stoją na straży rozwoju pracowników w firmie, powinny dążyć do osiągnięcia jak najbardziej zadowalających efektów, gdyż jest to istotne dla organizacji $\mathrm{z}$ punktu widzenia przetrwania $\mathrm{w}$ coraz bardziej konkurencyjnym środowisku. Uzyskanie zamierzonych efektów powinno przejawiać się zatem w okazywaniu

\footnotetext{
${ }^{10}$ Ibidem, s. 53.

${ }^{11}$ Ibidem, s. 54.

12 Ibidem, s. 54.
} 
zrozumienia drugiej stronie (pracownikom) i traktowaniu ich jako godnych rozwoju. Sun Tzu zaleca odnosić się do wszystkich z szacunkiem, uznaniem i godnością, nawet gdy ich aktualna sytuacja nie jest najlepsza. Daje to postawę do współpracy na linii dział personalny - pracownik oraz możliwość dostosowania się do zmian zachodzących w ciągle zmieniającym się otoczeniu, gdzie kooperacja jest obowiązkiem i koniecznością.

\section{Budowanie strategii personalnej}

Każdy dowódca, który decyduje się na udział w batalii wojennej, wie, że powinien mieć perfekcyjnie przygotowaną strategię działania - „ogólnie rzecz biorąc, najlepszą polityką wojny jest zachowanie bez szwanku swojego stanu" ${ }^{\prime 3}$. Kierując się tym przesłaniem, menedżer powinien znaleźć wspólny obszar, w który warto inwestować.

Jedna z głównych zasad głoszonych przez Sun Tzu głosi: „zaatakuj plany wroga $\mathrm{w}$ fazie ich powstawania" ${ }^{\text {". }}$. Tylko w takim przypadku możliwe będzie obranie odpowiedniej strategii dla personelu - gdy po odpowiedniej analizie potrzeb będzie wiadomo, na czym organizacja powinna skupić swoją uwagę. Już w fazie planowania działań oraz układania zasadniczej strategii menedżer powinien uwzględniać przewidywane posunięcia i kroki, które prawdopodobnie zostaną wykonane przez podległy personel (postawa zaangażowania, niechęci bądź oporu w procesie rozwoju kadr). Wczesne zwrócenie uwagi na zamiary personelu pozwoli na odpowiednie przeprowadzenie osób rzeczywiście zainteresowanych własnym rozwojem osobistym, zgodnie z oczekiwaniami kierowników i wymaganiami przedsiębiorstwa. Znając zdanie i plany podwładnych, stawiane przez nich realne wymagania oraz wyznaczone cele, odnoszące się do końcowych wytycznych, łatwiej będzie można podjąć odpowiednie decyzje w zakresie przyjętej taktyki. „Ci, którzy celują w rozwiązywaniu problemów, rozwiązują je tuż przed ich pojawieniem się. $\mathrm{Ci}$, którzy celują w pokonywanie swoich wrogów, zwyciężają zanim pojawi się zagrożenie" 15 - trafne przewidywanie intencji uczestników stwarza szanse na odpowiednie pokierowanie procesem szkoleniowym lub kształtowaniem ścieżek karier zawodowych.

Dodatkowo można upatrywać cennych wskazówek w obszarze modelowania strategii działania, podejmując kroki, wykraczające poza ramy własnej organizacji. Dobry menedżer powinien być zorientowany w ogólnej sytuacji, która panuje $\mathrm{w}$ zewnętrznym otoczeniu przedsiębiorstwa oraz znać techniki wykorzystywane przez konkurencję w danym sektorze a także siłę jej oddziały-

\footnotetext{
${ }^{13}$ Ibidem, s. 35.

${ }^{14}$ Ibidem.

${ }^{15}$ Ibidem, s. 36.
} 
wania. Informacje te powinny stać się podstawą do ustalenia, w jakich obszarach dana organizacja ma jeszcze braki, w których zaś zdecydowanie przoduje. Menedżer ma za zadnie również sprawdzenie niezależnych firm, które mogą wspomóc ich rozwój - zatem powinien uczynić wszystko, aby przekonać swoich pracowników, że szkolenia, w których przyjdzie im uczestniczyć, są naprawdę wyjątkowe i warto wykorzystać szansę na swój rozwój. Należy dodatkowo wyrobić w nich świadomość, że jest to najlepsza opcja i że od jej efektów zależy ich dalsza przyszłość.

Sun Tzu napisał, że „pożyteczną rzeczą jest uprzedzić atak przeciwnika”16 - podczas batalii wojennych przewage zdobywa ten, kto pierwszy zaatakuje i przejmie inicjatywę. Powyższa wskazówka odnosi się do wyjścia z propozycją do potencjalnych uczestników szkoleń, gdy posiada się już sprecyzowane cele, obraną taktykę oraz zarysowany plan działania. Skuteczny menedżer tak powinien pokierować rozmowami, aby kadra mogła dostrzec jego zaangażowanie $\mathrm{w}$ ich proces rozwoju. W istocie zaś będzie to swoistego rodzaju demonstracja siły i zaangażowania $\mathrm{w}$ realizację zamierzeń, które być może wcześniej zostały zasygnalizowane. Warto $\mathrm{w}$ tej sytuacji postawić na silne argumenty - dlatego należy zaangażować cały zespół w celu ich zweryfikowania oraz wybrania tych najbardziej rzetelnych. Kierownik, analizując bieg wydarzeń i sytuację, powinien w odpowiednim momencie zdecydować się na ich użycie. Dobry menedżer musi odznaczać się wysoko rozwiniętą zdolnością do realistycznej oceny sytuacji. Jeżeli $\mathrm{w}$ danej chwili organizacji nie stać finansowo na zorganizowanie perfekcyjnych, potrzebnych szkolen, to od jego decyzji zależy, kiedy ponownie ruszy dyskusja na ich temat.

Wnioski cząstkowe pozwalają więc na stwierdzenie, że jeżeli osobę zajmującą się rozwojem personelu cechuje dominująca pozycja i koncentracja, to dokładna analiza osób, które powinny wziąć udział np. w szkoleniu stwarza szansę na satysfakcjonujący efekt końcowy.

\section{Analiza wpływu Sztuki wojny Sun Tzu na strategie rozwoju personelu - w opinii ekspertów (badanie własne)}

W trakcie przeprowadzania analizy Sztuki wojny wykazano, że wiele rozdziałów posiada zalecenia, które mogą okazać się przydatne dla współczesnych działów zajmujących się rozwojem personelu. Jak dowiedziono, niektóre z nich w bezpośredni i jednoznaczny sposób można odnieść do różnorodnych elementów w procesie rozwoju kapitału ludzkiego, inne zaś pozostają symbolem i metaforą podejmowanych działań i zachowań, które występują w jego trakcie. Osoby, które zostaną wyznaczone na stanowiska menedżerskie w tym obszarze,

\footnotetext{
${ }^{16}$ Ibidem, s. 36.
} 
odnajdują wskazówki przede wszystkim w zakresie: odpowiednich cech charakterologicznych i osobowościowych, wyboru miejsc przeprowadzenia szkoleń, sposobu oraz odpowiedniego momentu wykorzystania posiadanych zasobów, opracowania efektywnej strategii działania, metod pozyskiwania kluczowych informacji o pracownikach oraz przygotowania się do wdrożenia zaproponowanych rozwiązań. Warto zauważyć, że wymienione wyżej elementy stanowią niewielki wycinek, w obrębie którego należy czerpać inspiracje z traktatu Sun Tzu. Duża doza mądrości i wiedzy, poparta dodatkowo niekwestionowanym doświadczeniem, które zostało wyniesione z pola walki zbrojnej, oraz efektywność przedstawionych wskazówek i metod daje odzwierciedlenie w używaniu ich przez dowódców i generałów w następnych epokach, a dodatkowo w ilości odwołań w nowożytnej literaturze często niepowiązanej z tematyką militarną.

W toku uzyskanych wniosków można zdecydowanie stwierdzić, że Sztuka wojny Sun Tzu może okazać się źródłem inspiracji i informacji dla współczesnych menedżerów w obszarze rozwoju personelu. Pragnienie przedstawienia odpowiedniego zbioru zasad przygotowania oraz prowadzenia strategii rozwoju personelu stało się głównym motywem do przeprowadzenia badań empirycznych w formie wywiadu eksperckiego. Stwierdzono, że opinia różnych ekspertów będzie niezbędnym warunkiem do weryfikacji wniosków, które zostały uzyskane w procesie analizy treści Sztuki wojny. Dodatkowo, niezmiernie ważną wartością było uzyskanie przekonań i poglądów w temacie omawianej problematyki, które pochodzą z kilku niezależnych od siebie źródeł, dając podstawę do dokonania obiektywnej i rzetelnej oceny wskazówek i przesłanek dla współczesnych menedżerów ds. rozwoju personelu, które zostały zawarte w dziele Sun Tzu.

Głównym celem przeprowadzenia wywiadu eksperckiego stało się przede wszystkim zebranie i odpowiednie opracowanie ich opinii, które pośrednio bądź bezpośrednio dotyczyły inspirowania się w procesie rozwoju personelu wiedzą, która pochodzi ze Sztuki wojny. Samo badanie poprzedziło staranne wyszukanie odpowiednich osób, które w ostateczności stanowiły grupę docelową i zgłosiły chęć uczestnictwa w projekcie. Zebrane dane jakościowe pozwoliły spojrzeć na badane zjawisko z szerokiej perspektywy ${ }^{17}$. Dzięki temu mają one charakter holistyczny i pokazują złożoność badanego obszaru ${ }^{18}$. Wytypowane osoby spełniały następujące kryteria: wykazały się ugruntowaną znajomością treści, które zostały zawarte w traktacie Sun Tzu Sztuka wojny, posiadały dostateczną wiedzę z zakresu sztuki wojennej oraz mądrość i doświadczenie w obszarze strategii rozwoju personelu. Przeprowadzone badanie przebiegało bez problemów i w sposób sprawny. Eksperci chętnie i z dużym zaciekawieniem wyrazili

${ }^{17}$ D. Silverman, Interpretacja danych jakościowych, Wydawnictwo Naukowe PWN, Warszawa 2007, s. 300.

${ }^{18}$ J. Kowal, Metody statystyczne w badaniach sondażowych rynku, Wydawnictwo Naukowe PWN, Warszawa 1998, s. 60. 
aprobatę na przeprowadzenie wywiadu. Ważnym aspektem okazała się kompetencja oraz prezentowanie sumiennego i odpowiedzialnego podejścia do zaproponowanego tematu. W zrozumiały i jasny sposób przekazali swoje opinie i spostrzeżenia, a udzielane przez nich odpowiedzi z całą pewnością należy uznawać za autorytatywne, stanowiące znakomity punkt odniesienia w przypadku dalszych rozważań.

Badania empiryczne są potwierdzeniem wniosków otrzymanych już w toku badań teoretycznych, a co za tym idzie pozwalają na sformułowanie na podstawie Sztuki wojny Sun Tzu uniwersalnego zestawu wskazówek i zasad, które mogą mieć zastosowanie $\mathrm{w}$ trakcie przygotowania i wdrażania strategii rozwoju personelu. Uogólnione wnioski z przeprowadzonych w dniach 14-20 maja 2012 r. wywiadów eksperckich przedstawiono poniżej.

Pierwsze pytanie wywiadu brzmiało: „Czy Pana/Pani zdaniem w prowadzeniu wojny i procesie rozwoju personelu można wyodrębnić wspólne cechy (elementy) oraz czy Sztuka wojny może stanowić inspirację dla współczesnej kadry menadżerów?" Opinie, które zostały sformułowane przez ekspertów, okazały się całkowicie zgodne i dały podstawę do wskazania, że prowadzenie wojny oraz strategii rozwoju personelu pociąga za sobą bardzo wiele analogii, wspólnych elementów oraz podobnych cech. Pomimo na pozór zupełnie odrębnej tematyki porównywanych obszarów widać zbliżone do siebie ich różnorodne aspekty zwłaszcza w zakresie: przygotowania się do odpowiedniego działania (wojny i rozwoju kapitału ludzkiego), prowadzenia działań, stosowania wielorakich taktyk, konieczności opracowania odpowiedniej strategii, doborze wykwalifikowanego personelu oraz wyborze właściwego miejsca. Choć prowadzenie wojny i doskonalenie zawodowe to dwie zupełnie odrębne sfery aktywności człowieka, to jednak eksperci wskazali pomiędzy nimi pewne wspólne elementy: celowość działania; osobiste predyspozycje (dowódców i pracowników); czas (zarówno wojna, jak i proces rozwoju personelu są zjawiskami rozciągniętymi w czasie); kapitał finansowy (jest niezbędny do prowadzenia działań wojennych; inwestowanie w kapitał ludzki również generuje ogromne koszty); wykorzystanie do osiągnięcia celu elementów zewnętrznych - uwarunkowania wynikające $\mathrm{z}$ otoczenia; celem wojny jest zwycięstwo, zaś długoterminowym celem strategii rozwoju personelu jest uzyskanie przewagi konkurencyjnej nad innymi organizacjami z tego samego sektora; im lepiej wyszkolona armia, tym większy jej potencjał - im bardziej wykwalifikowany personel, tym większa wartość firmy i siła organizacji; konieczność przygotowania (tworzenie planów taktycznych przed wojną i kreowanie strategii rozwoju personelu).

Rekapitulując odpowiedzi udzielane przez ekspertów na pierwsze z zadanych pytań, należy objąć stanowisko, że Sztuka wojny z całą pewnością jest źródłem inspiracji i wiedzy dla współczesnych menedżerów. Ponadto może ona stać się dodatkową lekturą dla osób, które chcą rozwijać się dodatkowo w tym obszarze zarządzania. 
Drugie pytanie w wywiadzie dotyczyło kwestii: „W jakich obszarach, Pana/Pani zdaniem, rozwiązania, pomysły i koncepcje realizowane na polu walki, o których pisał Sun Tzu, można współcześnie skutecznie realizować w procesie rozwoju personelu?" Odpowiedzi ekspertów potwierdziły, że prezentowane w dziele Sun Tzu instrukcje mogą z dużą dozą prawdopodobieństwa być wdrażane już podczas przygotowania strategii rozwoju personelu. Jednakże najważniejsze zalecenia wskazywane są już na etapie właściwego jej wdrażania. Zdaniem ekspertów, którzy uczestniczyli w badaniu, dyrektywy i wskazówki pochodzące ze Sztuki wojny należy przedstawić w następujących kategoriach:

- konieczność odpowiedniego przygotowania - zanim kierownik wskaże pracownikowi odpowiednią ścieżkę rozwoju, musi poznać jego plany, dążenia, perspektywy w danym miejscu zatrudnienia;

- odwaga dowódców w podejmowaniu strategicznych decyzji powinna przełożyć się na odwagę menedżerów w zakresie wytyczania celów i konsekwentnej ich realizacji;

- adaptacja do warunków walki (odpowiednia taktyka, dobór i wyposażenie czynnika ludzkiego, aby móc skutecznie oddziaływać na środek ciężkości przeciwnika) musi być podstawowym wyznacznikiem w zakresie umiejętności dostosowania się jednostki do wymagań dynamicznego otoczenia, zdolności adaptacji do zmian oraz możliwości przekwalifikowania;

- kalkulacja - tworzenie przez zespół kilku wariantów rozwoju oraz umiejętne szacowanie ryzyka,

- cel, który jest do osiągnięcia - na wojnie każda ze stron ma ściśle określony cel (może nim być zdobycie określonego punktu strategicznego przeciwnika, rozbicie głównej kolumny uderzeniowej, odparcie ataku wroga czy też ostateczne pokonanie nieprzyjaciela); w procesie rozwoju personelu menedżer również powinien wyznaczyć sobie konkretny cel, który chce osiągnąć (zdobycie przez personel konkretnej umiejętności, np. certyfikatu z języka obcego, czy też długofalowo - kreowanie ścieżek karier);

- spojrzenie na proces rozwoju personelu w sposób holistyczny

- „Zwycięży ten, którego żołnierze są zjednoczeni wolą zwycięstwa"19.

- inwestowanie w kapitał ludzki nie tylko będzie korzystne z punktu widzenia jednostki, ale przede wszystkim poprzez wykształconą i kompetentną kadrę zwiększy się ogólna wartość organizacji, co przemawia za tym, iż menedżerowie powinni wspierać pracowników w procesie doskonalenia zawodowego;

- potencjał armii (liczebność, wyszkolenie, środki rażenia jakimi dysponuje) w odniesieniu do potencjału kapitału ludzkiego w danej organizacji (wielkość przedsiębiorstwa i zespołów pracowniczych, wiedza i doświadczenie konkretnych pracowników oraz idealny menedżer pełniący rolę swoistego dowódcy);

\footnotetext{
${ }^{19}$ Sun Tzu, Sztuka wojny..., s. 40.
} 
- kierownicy przedsiębiorstwa i pracownicy muszą wiedzieć, w jakim kierunku zmierzają - „nie przewiduj w swoich planach zbędnych ruchów i ani jednego kroku w desperacji" ${ }^{20}$ - strategia rozwoju personelu powinna być dobrze przemyślana, aby nie inwestować w te obszary, które są nieopłacalne lub nie mają większego wpływu na funkcjonowanie organizacji;

- ocena warunków zewnętrznych (analiza firm funkcjonujących w otoczeniu bliższym i dalszym, badanie aktualnych trendów) - orientacja, w co warto inwestować obecnie, ale przede wszystkim nastawienie na przyszłość, aby organizacja potrafiła sprostać wymaganiom rynku;

- dowodzenie armią w stosunku do kierowania zespołem pracowniczym - powinny być obecne w procesie rozwoju personelu tendencje do szeroko pojętego coachingu i mentoringu - zespół powinien uczyć się od swojego lidera, ten zaś musi służyć radą i wspierać ich w każdym, wymagającym tego obszarze,

- osiąganie przewagi - w sztuce wojennej nazywana "zasadą wszystkich zasad” lub też „super zasadą" - zdobycie przewagi nad przeciwnikiem warunkuje zwycięstwo - w zarządzaniu personelem zaś inwestowanie w kapitał ludzki zwiększy wartość firmy, ale także wpłynie na jej konkurencyjność w otoczeniu i pomoże zdobyć dominującą pozycję na runku.

W trzecim pytaniu eksperci poproszeni zostali o przytoczenie konkretnych wskazówek (odnosząc się do wymienionych wcześniej zagadnień), które można wywnioskować z traktatu Sun Tzu w odniesieniu do zarządzania zasobami ludzkimi. Swoje wypowiedzi skupili przede wszystkim na podaniu następujących dyrektyw i zaleceń w zakresie strategii rozwoju personelu.

Odpowiednie dobranie oraz umiejętne przygotowanie zespołu ds. rozwoju kapitału ludzkiego - ma za zadanie wykazać się znajomością i wykorzystaniem w praktyce wszystkich elementów, które sprzyjają osiągnięciu celu. Powinny to być osoby starannie dobrane, gotowe do działania $\mathrm{w}$ zmiennych i różnych warunkach, posiadające odpowiednią motywację oraz emanujące właściwym potencjałem. Dodatkowo muszą posiadać pożądany zestaw cech, aby mogły pełnić przydzieloną $\mathrm{w}$ zespole rolę. Powodzenie w procesie rozwoju personelu w bardzo dużym stopniu uzależnione jest od efektywnej współpracy pomiędzy pracownikami.

Wybranie najkorzystniejszego wariantu działania - w ramach przygotowań do spotkań z pracownikami zespół powinien opracować różnorodne koncepcje i plany działania. To duże ułatwienie, gdy w danych okolicznościach będzie można wybrać ten spośród nich, który odznacza się największym współczynnikiem powodzenia. Nie należy jednak zapominać o otwarciu menedżera ds. rozwoju kapitału ludzkiego na ewentualne modyfikacje, ze względu na zmienność otaczających czynników.

${ }^{20}$ Ibidem, s. 52. 
W opinii ekspertów długie i odpowiednio dobre przygotowania są warunkiem sukcesu. Etap ten charakteryzuje się pozyskiwaniem i analizowaniem różnorodnych informacji nie tylko o środowisku zewnętrznym organizacji, ale także o własnych możliwościach i zajmowanej pozycji. Dopiero biorąc pod uwagę uzyskane wiadomości, można opracować ogólną koncepcję i strategię działania.

Za fundament sukcesu uznaje się generała - lidera zespołu ds. rozwoju personelu - to właśnie on posiada silny wpływ na pracę swojego zespołu. Jest odpowiedzialny za motywowanie do działania, podział obowiązków i zadań.

Dążąc do zamierzonego celu strategii rozwoju personelu, należy zadbać o dobór odpowiednich i odpowiedzialnych wykonawców, tak aby przełożyło się to na właściwy potencjał. Dlatego właśnie to ludzie, którzy wchodzą w skład zespołu ds. rozwoju kapitału ludzkiego w organizacji, stanowią o jego potędze. Posiadane przez nich umiejętności i predyspozycje mogą mieć istotny wpływ na efektywność stosowanych metod i powodzenie obranej strategii działania. Lider zespołu powinien posiadać zdolność do analitycznego myślenia - to właśnie w jego gestii leży rozpatrywanie korzystnych aspektów, ale także pojawiających się zagrożeń i negatywnych stron.

Sun Tzu wspominał, iż w trakcie działań zbrojnych dowódcy i żołnierze są narażeni na różne sytuacje - porażkę, upadek, ucieczkę, chaos czy nieposłuszeństwo. W procesie rozwoju personelu także dochodzi do niesprzyjających okoliczności - niepowodzenia, nawarstwiających się problemów, walki z czasem, braku jedności w zespole czy też ogólnego nieporządku. Warto zauważyć, że wyżej wymienione zjawiska nie mają nic wspólnego z wpływem niekontrolowanych sił, tylko ze skutkiem błędów, które są popełniane przez nieudolnych generałów, czy też niedoskonałych i niedoświadczonych menedżerów.

Traktat Sun Tzu Sztuka wojny jest bogaty w różnego rodzaju zalecenia, które można przenieść na grunt zarządzania personelem. Choć wokół tych praktyk powstają różne kontrowersje, to jednak wiele zależy od sposobu interpretacji poszczególnych zagadnień. Powyżej zostały przedstawione, dodatkowo opatrzone odpowiednim komentarzem, zalecenia i wskazówki, które w opinii ekspertów zostały zawarte w dziele Sun Tzu i mogą stać się wytycznymi dla współczesnych menedżerów. Podsumowując, są one zasadne do interpretacji Sztuki wojny Sun Tzu w kontekście procesu rozwoju personelu.

Uczestnicy, biorący udział w badaniu, jednoznacznie stwierdzili, że dzieło autorstwa Sun Tzu może być źródłem wiedzy i inspiracji dla współczesnych menedżerów specjalizujących się $\mathrm{w}$ rozwoju personelu. Wskazali oni szereg podobieństw występujących pomiędzy wojną a strategią rozwoju personelu i dla tych obszarów wyprowadzili wiele zaleceń i wskazówek, które z sukcesem można zrealizować na obu rozpatrywanych płaszczyznach. Ich imponująca liczba wydaje się dość zaskakująca, biorąc pod uwagę odmienność obszarów zainteresowań sztuki wojny i strategii rozwoju kapitału ludzkiego. Niemniej 
jednak, wytyczne związane z opracowaniem strategii działania i taktyki, przygotowaniem, planowaniem kolejnych przedsięwzięć i kroków, sposobami kierowania ludźmi - są tak samo istotne w przypadku obu dziedzin i dodatkowo wymagają odpowiednich umiejętności, doświadczenia i wiedzy od ich wykonawców. Informacje i mądrości, które zostały zawarte w dziele starożytnego filozofa i dowódcy Sun Tzu, zostały już zweryfikowane na przestrzeni wielu wieków, gdzie jednocześnie ich skuteczność wielokrotnie była sprawdzana w praktyce. Dlatego uznano, że staną się one wzorem do naśladowania, czy też najlepszym punktem odniesienia dla wszystkich osób, które chcą zawodowo zajmować się zagadnieniami towarzyszącymi rozwojowi kapitału ludzkiego w organizacjach.

\section{Zakończenie}

Wojna (odzwierciedlająca stan stosunków politycznych i społecznych, z bardzo kontrowersyjnym osiąganiem celów przy pomocy środków zbrojnych) i rozwój zasobów ludzkich stanowią zagadnienia, które pochodzą z dwóch, całkowicie odmiennych dziedzin nauki. Pierwotnie może się wydawać, że nie ma sensu i podstaw do doszukiwania się elementów, które w jakikolwiek sposób łączyłyby obie kwestie. Jednakże dogłębna analiza dostępnej literatury przedmiotu oraz przeprowadzone badania empiryczne w postaci wywiadu eksperckiego wskazują na występowanie wspólnych cech w zakresie prowadzenia wojny i strategii rozwoju personelu: działania reaktywne, duża rola w procesie samego przygotowania, stosowanie różnorodnych taktyk i zabiegów, które umożliwią osiągnięcie celu - to jedne z bardzo wielu, dających się zauważyć analogii.

Można pokusić się o stwierdzenie, że zalecenia, które zostały zaprezentowane w niniejszym artykule, mogą stać się nieocenioną pomocą podczas przygotowywania i wdrażania strategii rozwoju personelu, jednakże pod warunkiem, że osoba za to odpowiedzialna będzie odznaczała się odpowiednimi kwalifikacjami i umiejętnościami. Dobry menedżer będzie w stanie zdobyć i utrzymać przewagę oraz kontrolę nad zaproponowanym procesem a dodatkowo stosując się do przedstawionych przez Sun Tzu reguł i praw, pewnie i świadomie go poprowadzi.

\section{Literatura}

Adamiec M., Zarzadzanie zasobami ludzkimi. Aktor, kreator, inspirator, Wydawnictwo Akademickie, Katowice 2000.

Amstrong A., Zarządzanie zasobami ludzkimi, Wolters Kluwer Polska- OFICYNA, Kraków 2007. Cowan C., Parent G., Sztuka wojny w miłości, Helion, Gliwice 2009.

Dean L., Sun Tzu, Sztuka wojny dla graczów giełdowych i inwestorów, IFC PRESS, Kraków, 1999. 
Gagliardi G., Sun Tzu, Sztuka wojny. Sztuka marketingu, Helion, Gliwice 2005.

Gagliardi G., Sztuka wojny. Sztuka planowania kariery, Helion, Gliwice 2005.

Gryffin R. W., Podstawy zarządzania organizacjami, PWN, Warszawa 1996.

Jomini H., Zarys sztuki wojennej, MON, Warszawa 1996.

Kowal J., Metody statystyczne w badaniach sondażowych rynku, Wydawnictwo Naukowe PWN, Warszawa 1998.

Koziej S., Teoria sztuki wojennej, Bellona, Warszawa, 1993.

Koźmiński A., W. Piotrowski, Zarzadzanie - teoria i praktyka, PWN, Warszawa, 1995.

Krause D. G., Sztuka wojny w biznesie, Helion, Gliwice 2009.

Lipka A., Strategie personalne firmy, Wydawnictwo Profesjonalnej Szkoły Biznesu, Kraków 2000.

Listwan T., Zarzadzanie kadrami, Wydawnictwo C.H. Beck, Warszawa 2006.

Ludwiczyński A., Stobińska K., Zarządzanie strategiczne kapitałem ludzkim, Poltext, Warszawa 2001.

Pocztowski A. (red.), Funkcja personalna. Diagnoza i kierunki zmian, Wydawnictwo UE w Krakowie, Kraków 2007.

Pomianek T., Zarządzanie zasobami ludzkimi, WSIiZ, Rzeszów 1999.

Silverman D., Interpretacja danych jakościowych, PWN, Warszawa 2007.

Sun Tzu, Sztuka wojny, Helion, Gliwice 2012.

Tomaszewski A., Podstawowe kategorie sztuki wojennej, AON, Warszawa 1996.

http://comma.dt.pl/e-books/BingFa/Screen/SCREEN.pdf.

http://comma.dt.pl/e-books/BingFa/Screen/SCREEN.pdf.

\section{Streszczenie}

Opracowanie dotyczy problematyki strategii rozwoju personelu, lecz $\mathrm{w}$ bardzo nietypowym, często dyskusyjnym ujęciu. Praca zawiera bardzo szczegółową analizę oraz interpretację uniwersalnych treści zawartych w Sztuce wojny autorstwa Sun Tzu, w odniesieniu do inspiracji, wskazówek oraz zasad, pomocnych w trakcie przygotowania i prowadzenia strategii rozwoju personelu.

\section{Summary}

\section{SUN TZU ART OF WAR AS THE BASIS FOR STAFF DEVELOPMENT STRATEGY}

The paper deals with the issues of the staff development strategy in unusual and controversial approach. The content is the result of a careful analysis of the world's first handbook, which deals with the art of war, written by Sun Tzu - for inspiration, guidance and principles that will help in the preparing and conducting staff development strategy. Selected treaty became the foundation to draw up a concept that can be a source of information for those interested in the area of management science, in particular the development of human capital. 